\title{
Fluoxetine-Associated Sleep Disorders-Report of Two Cases and Literature Review
}

\section{Fluoksetin Kaynaklı Uyku Bozuklukları: Iki Olgu Sunumu ve Literatür Derlemesi}

\author{
๑ Leyla Köse Leba, ๑ Aylin Bican Demir* \\ Necmettin Erbakan University Meram Medical Faculty, Department of Neurology, Konya, Turkey \\ *Bursa Uludağ University Faculty of Medicine, Department of Neurology, Bursa, Turkey
}

\begin{abstract}
Narcolepsy is a condition characterised by excessive daytime sleepiness, cataplexy, hypnogogic hallucination and sleep paralysis. Sleep-related eating disorder (SRED) is a parasomnia that occurs while sleeping and manifests itself as paroxysmal episodes of involuntary eating and/or drinking. Both sleep disorders often occur as primary conditions. Sleep disorders secondary to medical treatment less often occur. This report presents the case of a patient with narcolepsy and another with SRED as a result of anamnesis and polysomnography. These sleep disorders are due to recently initiated fluoxetine treatment. Sleep disorder occurring as secondary to medication has been ignored because it has eluded the clinicians.
\end{abstract}

Keywords: Narcolepsy, sleep-related eating disorder, fluoxetine, SRED, PSG
Öz

Narkolepsi; gündüz aşırı uyku hali, katapleksi, hipnogojik halüsinasyon, uyku paralizisi ile karakterize bir hastalıktır. Uyku ile ilgili yeme bozukluğu (SRED); uyku sırasında ortaya çıkan, paroksismal, istem dışı yemek yeme ve/veya içme epizodları ile seyreden bir parasomni tablosudur. Her iki uyku bozukluğu da sıklıkla primer olarak ortaya çıkmaktadır. Medikal tedaviye sekonder olarak ortaya çıkan olgu daha nadirdir. Bizim sunduğumuz yazıda, anamnez ve polisomnografi incelemesi sonucunda bir hastada narkolepsi, diğer hastada SRED tanıları düşünüldü ve bu durumların yeni başlanan fluoksetin tedavisine sekonder olduğu kararına varıldı. İlaca sekonder oluşan uyku bozukluğu klinisyenler tarafından akla gelmediği ve sorgulanmadığı için inmal edilmektedir.

Anahtar Kelimeler: Narkolepsi, uyku ile ilişkili yeme bozukluğu, fluoksetin, SRED, PSG

\section{Introduction}

\section{Narcolepsy}

Narcolepsy is a sleep disorder occurring with $90-95 \%$ loss of hypocretin neurons (1) and is mostly seen between 10 and 25 years. It is a disease characterized by excessive daytime sleepiness (EDS), cataplexy, hypnogogic hallucination, and sleep paralysis. It interrupts patients' sleep. Although they have no problem with drifting into sleep, maintaining sleep is difficult for them (2).

EDS is the main symptom and the most common reason of the sleep disability. It cannot be prevented during the day. Repeated episodes of sleep attacks take a short time and they are relaxing. Cataplexy is defined as a repetitive sudden muscle tone loss without loss of consciousness and often takes less than 2 minutes. Hypnogogic hallucinations are accepted as an experience of vivid like dreams while drifting into sleep. Sleep paralysis is characterized with temporary muscle paralysis while passing awakening from sleep $(2,3)$.

It is required in order to diagnose that sleep latency should be 8 minutes or less on multiple sleep latency test (MSLT) and at least 2 sleep-onset REM (SOREM) periods should be experienced at the beginning of sleep.

SOREM observed within the first 15 minutes on polysomnography (PSG) can substitute one of the SOREM on MSLT. It is referred to as "type 2 " in the presence of cataplexy or when hypocretin-1 level is detected as $\leq 110 \mathrm{pg} / \mathrm{mL}$ in cerebrospinal fluid (4). It is evaluated as "type-2" if hypocretin level is normal and cataplexy does not accompany it.

\section{Sleep-Related Eating Disorder (SRED)}

Parasomnias are undesirable motor, verbal or behavioral cases occurring during any stage of sleep, including while drifting

Address for Correspondence/Yazışma Adresi: MD Leyla Köse Leba, Necmettin Erbakan University Meram Medical Faculty, Department of Neurology, Konya, Turkey Phone: +90 5337248407 E-mail: leylakos_e@hotmail.com ORCID-ID: orcid.org/0000-0002-5989-6548 Received/Geliş Tarihi: 16.02.2021 Accepted/Kabul Tarihi: 28.04.2021

${ }^{\circ}$ Copyright 2021 by Turkish Sleep Medicine Society / Journal of Turkish Sleep Medicine published by Galenos Publishing House. 
into sleep, sleeping or waking up. They can occur in both REM and non-REM (NREM) periods. Consciousness and awareness are affected in NREM parasomnias and amnesia accompanies them (4). Although they often begin in childhood, they can rarely occur in adulthood.

SRED takes part in NREM parasomnia group. Repetitive abnormal eating attacks after wakefulness reaction in sleep, at least one of those occasions (odd combination of food consumption, sleep-related injuries, health problems after repetitive eating attacks in sleep), and partial or complete loss of consciousness in the course of eating attack should be experienced in order to diagnose it (4). PSG is important to identify other sleep disorders but not compulsory. Besides that the presence of wakefulness in non-REM sleep shown during PSG recording is also supportive for diagnosis.

That there are both retrograde and anterograde amnesia in SRED attacks makes getting detailed information related to the attack difficult. Taking anamnesis of patient relatives can also be beneficial in order to obtain useful information for diagnosis. In this study, two cases have been presented with regard to narcolepsy secondary to medication and SRED diagnosis which affect sleep architecture and life quality significantly. EDS complaints have been taken into consideration in these cases.

\section{Clinical Summary}

\section{Case 1}

A 30-year female patient applied us with EDS and the complaint of eating in sleep.

The patient expresses that she has been looking after her mother receiving cancer treatment for 6 years. She has been followed up with depression diagnosis by a psychiatrist and has been using $20 \mathrm{mg}$ fluoxetine for the last two years. She has been complaining about eating in sleep increasingly for the last one year. Once a week, she leaves her bed early night and wanders and eats something in the kitchen mostly but also in other rooms of her house. The patient expresses that she is difficulty in remembering her experiences but her husband realizes them.

She has been found out in the bathroom by her husband most recently while trying to eat a soap. She has gained $12 \mathrm{~kg}$ of weight for the last six months. The patient whose neurologic examination is natural and routine EEG and cranial MR are normal has been observed with eating attack in NREM period on PSG (Figure 1, 2).

It has been revealed that she has not realized the technicians coming into the room, has not answered the questions addressed her, and has not remembered this attack when she wake up. Topiramate has been started to the patient and fluoxetine has been discontinued by the psychiatrist. The eating fact of the patient has been removed completely. She has been following up without medication.

\section{Case 2}

A 21-year female patient applied us with EDS. She has been complaining about this situation for 6 months. She has unbearable sleep attacks and for this reason she has had to short-term sleep. Sometimes, she has sleep desire 5-6 times a day. She can sleep 14-15 hours at weekends. Fluoxetine has been started to the patient by a primary care physician due to the immense anxiety in a period that she is in another city because of the university education.

She has been using it for almost 10 months. The PSG of the patient whose neurologic examination is natural and routine EEG and cranial MR are normal has been observed SOREM period (Figure 3) and three-fifth of REM has also been observed on MSLT performed on the following day (Figure 4). 200 $\mathrm{mg} /$ day of modafinil has been started to the patient and the fluoxetine has been discontinued. The complaints of the patient has been removed after discontinuing the medication and the control has ended up as normal on PSG. The patient has been following up without medication.

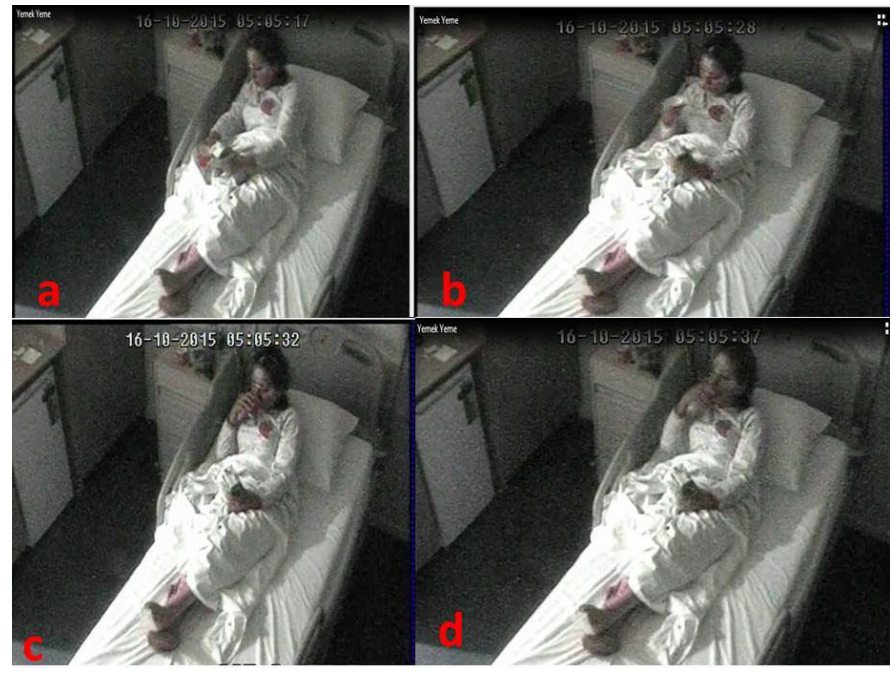

Figure 1. The patient wakes up in NREM sleep and drinks something

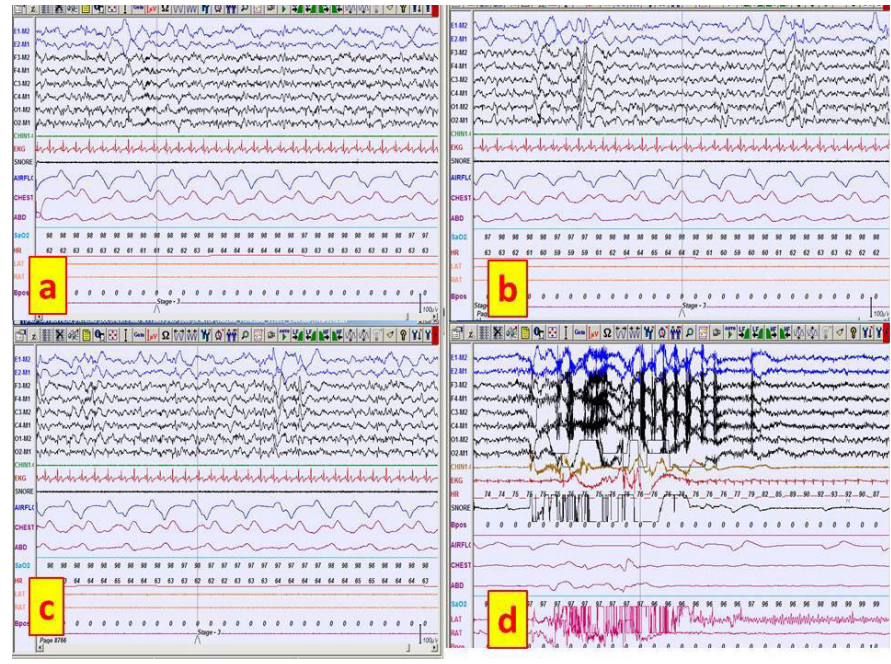

Figure 2. PSG sample in NREM eating attack

PSG: Polysomnography, NREM: non-REM 


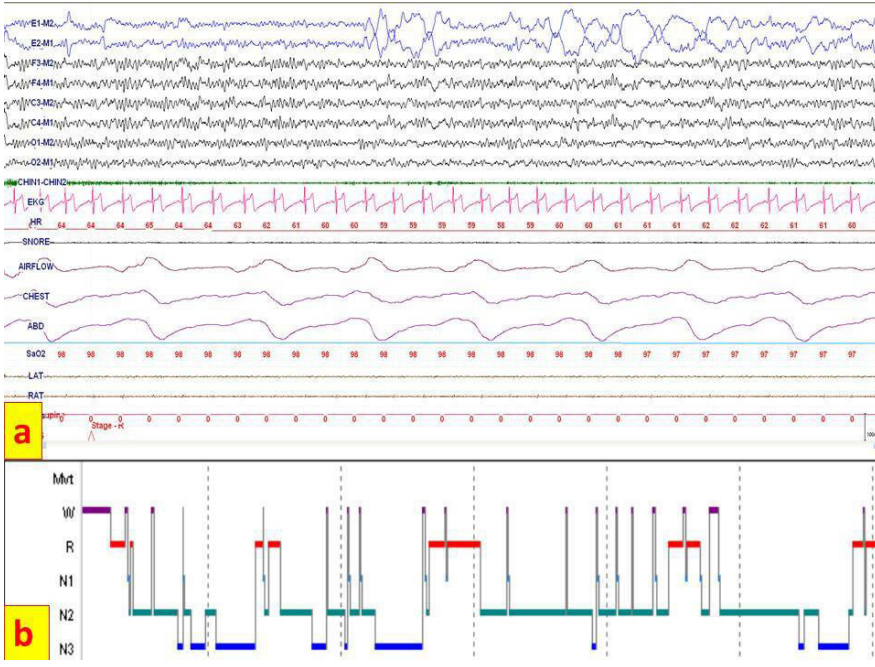

Figure 3. Sleep-onset REM sample and hypnogram

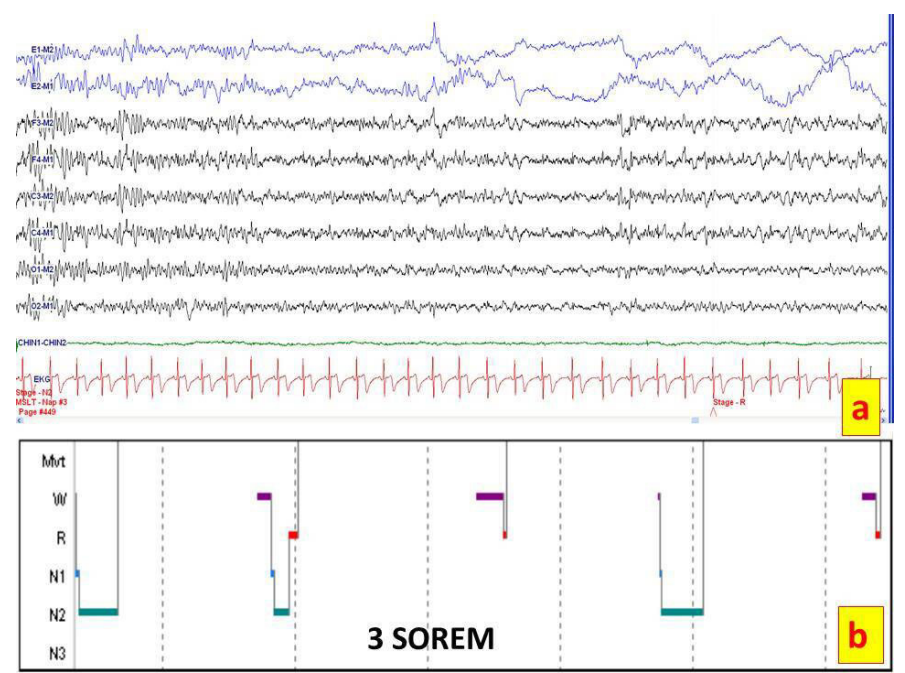

Figure 4. EEG sample performed on the following day and 3/5 REM hypnogram

SOREM: Sleep-onset REM, EEG: Electroencephalography

\section{Discussion}

Parasomnia and narcolepsy attacks, other sleep disorders, in the first place sleep deprivation, fragmented sleep architecture, stress, and sleep apnea can be triggered by environmental and endogenic stimulus like drug, alcohol or substance use $(5,6)$.

Narcolepsy and SRED can also be secondary to medical treatment. It may be right using terminologically secondary narcolepsy or SRED for these cases (4). PSG and MSLT should definitely be performed on a patient considered with narcolepsy. PSG is required in order to research other sleep disorders underlying NREM parasomnia cases starting in adult age group.

Medical agents related to SRED are benzodiazepines, benzodiazepine receptor agonists, mirtazapine, risperidone, quetiapine, lithium, and anticholinergic drugs (7). Narcolepsy cases developing after vaccine and interferon treatment have also been reported.

It is known that selective serotonin reuptake inhibitors (SSRI) can reduce sleep quality with the activation of serotonergic 5-HT2 receptors.

SSRI can put REM period back, even repress. It can also disrupt sleep continuity and reduce sleep efficiency (8). It is revealed that insomnia and somnolence complaints are frequent in patients treated with SSRI (9).

It is known that SSRI induces sleep bruxism and REM sleep behavior disorder $(8,10)$. Fluoxetine is a commony used SSRI. It is usually used in obsessive-compulsive disorder, panic attack, and depression treatment (11). It has an important role in narcolepsy treatment, particularly in reducing cataplexy. It is reported that cataplexy attacks increase with the rapid discontinuation of the medication (12). It is pointed out that monkeys treated with fluoxetine have sleep fragmentation (13). It is also known that sleep bruxism is triggerred with fluoxetine usage $(14,15)$.

Narcolepsy or SRED case revealing as a result of fluoxetine usage is not reported in literature. Our cases are remarkable due to the fact that one of them is narcolepsy developing secondarily after fluoxetine, and the other one is SRED. In both patients, sleep disorder has started in adulthood and there is no another detected sleep disorder on PSG. Disappearing of the complaints completely with the discontinuation of the medication supports the diagnosis. Even though, there is a role of fluoxetine on narcolepsy treatment, it should be kept in mind that it can trigger some sleep disorders like bruxism and parasomnia.

\section{Conclusion}

As a consequence, these two cases have been presented in order to draw attention to the sleep disorders triggered by fluoxetine and to lay emphasis on whether there is a recently initiated medication or not before diagnosing primary sleep disorder.

\section{Ethics}

Peer-review: Externally peer-reviewed.

\section{Authorship Contributions}

Concept: L.K.L., A.B.D., Design: L.K.L., A.B.D., Data Collection or Processing: L.K.L., A.B.D., Analysis or Interpretation: L.K.L., A.B.D., Literature Search: L.K.L., A.B.D., Writing: L.K.L., A.B.D.

Conflict of Interest: No conflict of interest was declared by the authors.

Financial Disclosure: The authors declared that this study received no financial support.

\section{References}

1. Thannickal TC, Moore RY, Nienhuis R, Ramanathan L, Gulyani S, Aldrich M, Cornford M, Siegel JM. Reduced number of hypocretin neurons in human narcolepsy. Neuron 2000;27:469-74.

2. Dauvilliers $\mathrm{Y}$, Arnulf I, Mignot E. Narcolepsy with cataplexy. Lancet 2007;369:499-511. 
3. Burgess CR, Scammell TE. Narcolepsy: neural mechanisms of sleepiness and cataplexy. J Neurosci 2012;32:12305-11.

4. Sateia MJ. International classification of sleep disorders-third edition: highlights and modifications. Chest 2014;146:1387-94.

5. Broughton RJ, Shimizu T. Sleep-related violence: a medical and forensic challenge. Sleep 1995;18:727-30.

6. Pressman MR. Factors that predispose, prime and precipitate NREM parasomnias in adults: Clinical and forensic implications. Sleep Med Rev 2007;11:5-30.

7. Vinai P, Ferri R, Ferini-Strambi L, Cardetti S, Anelli M, Vallauri P, Ferrato N, Zucconi M, Carpegna G, Manconl M. Defining the borders between Sleep-Related Eating Disorder and Night Eating Syndrome. Sleep Med 2012;13:686-90.

8. Wichniak A, Wierzbicka A, Jernajczyk W. Sleep and Antidepressant Treatment. Curr Pharm Des 2012;18:5802-17.

9. Thompson C. Onset of action of antidepressants: results of different analyses. Hum Psychopharmacol 2002;17(Suppl 1):S27-32.
10. Wilson S, Argyropoulos S. Antidepressants and sleep. Drugs 2005;65:927-47.

11. Stoyek MR, Jonz MG, Smith FM, Croll RP. Distribution and chronotropic effects of serotonin in the zebrafish heart. Auton Neurosci 2017;206:43-50.

12. Poryazova R, Siccoli M, Werth E, Bassetti CL. Unusually prolonged rebound cataplexy after withdrawal of fluoxetine. Neurology 2005;65:967-8.

13. Golub MS, Hogrefe CE. Sleep disturbance as detected by actigraphy in pre-pubertal juvenile monkeys receiving therapeutic doses of fluoxetine. Neurotoxicol Teratol 2016;55:1-7.

14. Colak Sivri R, Akça ÖF. Buspirone in the Treatment of FluoxetineInduced Sleep Bruxism. J Child Adolesc Psychopharmacol 2016;26:762-3.

15. Akbaş B, Bilgiç A. Fluoxetine-Induced Sleep Bruxism Rapidly Treated With Once-Nightly Dosing of Buspirone in a 6-Year-Old Girl. Clin Neuropharmacol 2018;41:197-8. 